DOE/NASA CONTRACTOR REPORT
DOE/NASA CR-150857

December 1978

\title{
THERMAL PERFORMANCE EVALUATION OF THE SOLARGENICS SOLAR COLLECTOR AT OUTDOOR CONDITIONS
}

Prepared by

Wyle Laboratories

Solar Energy Systems Division

Huntsville, Alabama 35805

Under subcontract with

IBM Corporation, Federal Systems Division, Huntsville, Alabama 35805

Contract NAS8-32036

National Aeronautics and Space Administration

George C. Marshall Space Flight Center, Alabama 35812

For the U. S. Department of Energy

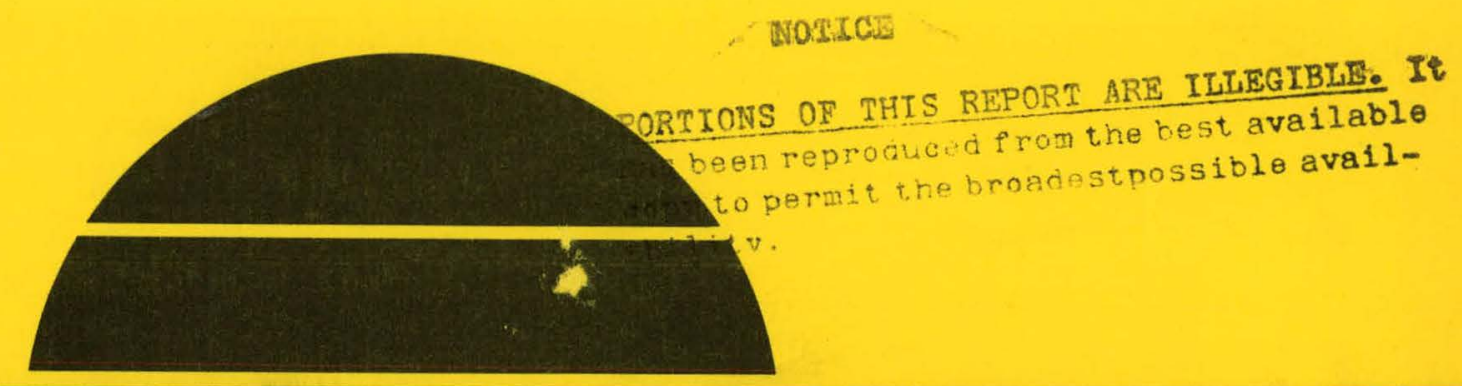

\section{U.S. Department of Energy}




\section{DISCLAIMER}

This report was prepared as an account of work sponsored by an agency of the United States Government. Neither the United States Government nor any agency Thereof, nor any of their employees, makes any warranty, express or implied, or assumes any legal liability or responsibility for the accuracy, completeness, or usefulness of any information, apparatus, product, or process disclosed, or represents that its use would not infringe privately owned rights. Reference herein to any specific commercial product, process, or service by trade name, trademark, manufacturer, or otherwise does not necessarily constitute or imply its endorsement, recommendation, or favoring by the United States Government or any agency thereof. The views and opinions of authors expressed herein do not necessarily state or reflect those of the United States Government or any agency thereof. 


\section{DISCLAIMER}

Portions of this document may be illegible in electronic image products. Images are produced from the best available original document. 
This report was prepared to document work sponsored by the United States Government. Nelther the United States nor 1ts agents the Unfted States Departmant of Energy, the United States Nat1onal Aeronautics and Space Adminletration, nor any federal employees, nor any of thef: contractors, stikcritractors or their employees, make any warranty, express or 1miflted, or assume any legal 11ability or responsibility for the acculacy, completeness, or usefulness of any information, apparatus, product or process disclosed, or represent that its use would not infringe privately owned rights. 


\begin{tabular}{|c|c|c|}
\hline $\begin{array}{l}\text { 1. REPORT NO. } \\
\text { DOE/NASA CR-150857 }\end{array}$ & 2. GOVERNMENT ACCESSION NO. & 3. RECIPIENT'S CATALOG NO. \\
\hline \multirow{2}{*}{\multicolumn{2}{|c|}{$\begin{array}{l}\text { 4. TITLE AND SUBTITLE } \\
\text { Thermal Performance Evaluation of the Solargenics Solar } \\
\text { Collector at Outdoor Conditions }\end{array}$}} & $\begin{array}{l}\text { 5. REPORT DATE } \\
\text { December } 1978\end{array}$ \\
\hline & & 6: PERFORMING ORGANIZATION CODE \\
\hline \multicolumn{2}{|c|}{ 7. AUTHOR(S) } & 8. PERFORMING ORGANIZATION REPORT \# \\
\hline \multicolumn{2}{|c|}{ 9. PERFoRmING ORGaNIzATION NAME AND adoress } & 10. WORK UNIT, NO. \\
\hline \multirow{2}{*}{\multicolumn{2}{|c|}{$\begin{array}{l}\text { Wyle Laboratories } \\
\text { Solar Energy Division } \\
\text { Huntsville, Alabama }\end{array}$}} & $\begin{array}{l}\text { 11. CONTRACT OR GRANT NO. } \\
\text { NAS8-32036 }\end{array}$ \\
\hline & & \multirow{2}{*}{$\begin{array}{l}\text { 13. TYPE OF REPORT \& PERIOD COVERED } \\
\text { Contractor Report }\end{array}$} \\
\hline \multirow{2}{*}{\multicolumn{2}{|c|}{$\begin{array}{l}\text { 12. SPONSORING AGENCY NAME AND ADORESS } \\
\text { National Aeronautics and Space Administration } \\
\text { Washington, D. C. } 20546\end{array}$}} & \\
\hline & & 14. SPONSORING AGENCY CODE \\
\hline
\end{tabular}

15. SUPPLEMENTARY NOTES

This work was done under the technical management of Mr. Charles N. Thomas, George C. Marshall Space Flight Center, Alabama.

16. ABSTRACT

Information contained within this report presents test procedures used during the performance of an evaluation program. The test program was conducted to obtain the following performance data and information on the solar collector.

- Thermal performance data under outdoor conditions

- Structural behavior of collector under static conditions

- Effects of long term exposure to material weathering elements

The Solargenics is a liquid, single-glazed, flat-plate collector. Approximate dimensions of each collector are 240 inches long, 36 inches wide, and 3.5 inches in depth.

All testing activities were conducted at the Marshall Space Flight Center's Breadboard Facility, and the thermal performance evaluations were made under natural outside conditions.

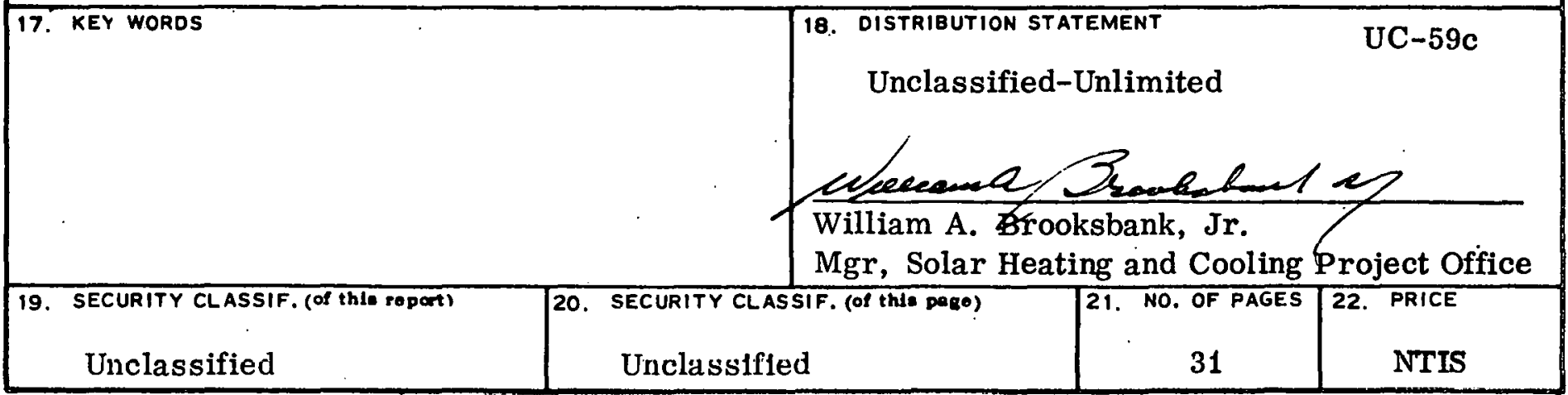


THIS PAGE

\section{WAS INTENTIONALLY LEFT BLANK}


Page No.

1.0

PURPOSE

REFERENCES

TEST CONDITIONS AND TEST EQUIPMENT

5.1 Ambient Conditions

5.2 Instrumentation and Equipment

5.3 Data Acquisition Systems

6.1 Collector Preconditioning and Stagnation Test

6.2 Collector Time constant Test

6.3 Collector Thermal Efficiency Test

6.4 Incident Angle Modifier Test

6.5 Collector Load Test

7.1 Thermal Performance Test

7.2 Time Constant Test

7.3 Incident Angle Modifier Test

TABLE I

TABLE II

TABLE III

TABLE IV

TABLE V

Figure 1

Figure 2

DESIGNATION OF INSTRUMENTATION FOR SIMULATOR TESTS

SOLARGENICS COLLECTOR STAGNATION TEST RESULTS

THERMAL PERFORMANCE TEST DATA FOR THE SOLARGENICS COLLECTOR

INCIDENT ANGLE MODIFIER TEST DATA FOR THE SOLARGENICS COLLECTOR

RESULTS OF LOAD TESTING

Instrumentation Locations for Liquid Collector Test

Schematic of the Solargenics Collector with Stagnation Temperature Sensor Locations 
TABLE OF CONTENTS (Continued)

Page No.

Figure 3. Time Constant Test of the Solargenics Collector

Figure 4

Solargenics Collector Performance for Outdoor Test at 1.57 GPM

Figure 5

Incident Angle Modifier Test for the Solargenics Collector 
The purpose of this document is to present the test procedures used during the performance of an evaluation program. The test program was conducted to obtain the following performance data and information on the solar collector:

- Thermal performance data under outdoor conditions.

- Structural behavior of the collector under static loading conditions.

- Effects of long-term exposure to natural weathering elements.

All testing activities were conducted at the MSFC Breadboard Test Facility, and the thermal performance evaluations were made under natural outside conditions. The test was conducted and the data evaluated using the methods provided in Reference 2.1 as applicable to outdoor testing of solar collectors. The effects of longterm exposure to natural weathering will be conducted and reported at a later date.

$2.0 \quad$ REFERENCES

2.1. ASHRAE 93-77

Method of Testing to Determine the Thermal Performance of Solar Collectors

COLLECTOR DESCRIPTION

Manufacturer:

Manufacturer's Address:

Mode1 Number:

Serial Number:

Type :

Working Fluid:
Solargenics

808 Grctna Green Way

Los Angeles, California

None

None

Flat Plate

$\mathrm{H}_{2} \mathrm{O}$ 
Gross Collector Area, $\mathrm{ft}^{2}: 63.54 \mathrm{ft}^{2}$

overall external dimensions:

width, inches:

Length, inches: Thickness, inches: Aperture area, $\mathrm{ft}^{2}$ :

Collector glazing:

Weight, lbs:
38.12

240.00

$3-7 / 8$

53.34

single

(Not available.)

4.0 SUMMARY

Thermal performance tests have been conducted on a Solargenics solar collector, prior to long-term weather exposure evaluations. (Weather exposure evaluations are to be performed as part of this test program, and the results will be reported separately at their conclusion.) 'l'he collector efficiency, thermal response time and incident angle modifier test results are presented in Section 6 . Graphical presentations of the thermal response time, collector efficiency and incident angle modifier test results comprise Figures 3 through 5, respectively.

Measurements of stagnation temperatures are presented in Table II.

The results of the structural load evaluations are contained in Table $\mathrm{V}$. 


\begin{abstract}
5.0 TEST CONDITIONS AND TEST EQUJPMENT
5.1 Ambient Conditions

Unless otherwise specified herein, all tests were performed at ambient conditions existing at rest Bed $\$ 2$ of the MSFC Solar Test Facility at the time of the tests.
\end{abstract}

5.2

Instrumentation and Equipment

All test equipment and instrumentation used in the performance of this test program comply with the requirements of MSFC-MMI-5300.4C, Metrology and Calibration. Table I contains instrumentation identification and data acquisition connection data. Instrumentation locations on the test loop and collector are depicted in Figure 1 . A listing of the equipment used in each test follows.

Apparatus

Platinum Resistance Thermometer

Pyranometer

Liquid Loop

Flow Meter

Platinum Resistance Thermometer.

Strip Chart Recorder

Wina Direction Sensor

wind Velocity Sensor

Differential Pressure Transducer
Manufacturer/Model

Supplied by Collector Manufacturer

Eppley - PSP

MSFC Supplied

Foxboro/1/2-2 81T3Cl

Hy-Ca 1

Mosley 680

Teledyne Geotech/M1567

Teledyne Geotech/M1567

statham
Range/Accuracy

$0-500^{\circ} \mathrm{F} \pm 0.5^{\circ} \mathrm{F}$

$0-800 \mathrm{BTU} / \mathrm{Ft} \mathrm{t}^{2} \cdot \mathrm{Hr}$ $\pm 38$

$.1-1.2 \mathrm{GPM}$ $i 1-.91 \pm 18 \mathrm{GPM}$

$0-500^{\circ} \mathrm{F} \pm 0.5^{\circ} \mathrm{F}$

5-500 MV \pm 28

$0-360^{\circ} \pm 18$

$0.75-60 \mathrm{mph} \pm 1 / 28$

All transducers with the exception of the Eppley PSP pyranometer used in recording test data are calibrated by either NASA or AMC calibration laboratories as required by MSFC MMI 5300.4C. The PSP pyranomoter was ralibrated by the manufacturer. The stated accuracy of individual transducers reflects the overall expected accuracy through the data acquisition system. 
5.3 Data Acquisition Systems

Test data obtained during performance tests was transmitted from the test site through the primary data acquisition system \#l. to the real time data link and the DDP-224 computer located in MSFC Building 4646 . separate data link from Building 4646 provided for printout of real time data at the test site.

The end-to-end acouracy of data derived from performance testing was subject to an error analysis which acoounte for all inaccuracies in the transducer, signal conditioning, signal transmission, and computer processing methods. Since a formal systems error analysis was not done, confidence in printout accuracies was established by installing calibrated "parallel" transducers and direct readouts at key points in the system and performing comparison checks from time to time before, during, and after tests. The results of such checks together with a review of the data for anomalies indicated that the data presented is suitable for the purpose intended. 
Tested By: B. Henderson
Started:
$8 / 1 / 78$

Completed:

$8 / 1 / 78$

\section{1 .1 Requirement}

The collector shall be mounted on an outdoor passive test stand at an angle of $10^{\circ}$ from the horizontal and facing south. The inlet and outlet ports to the collector shall be capped to prevent flow. The upper cap shall contain a small vent hole. The preconditioning shall consist of at least three days exposure during which the mean incident solar radiation measured in the plane of the collector shall be $1500 \mathrm{BTU} / \mathrm{Ft}^{2} \cdot \mathrm{day}$. During this preconditioning, the following data shall be recorded within two hours of solar noon when the insolation is constant and above a minimum of $200 \mathrm{BTU} /$ $\mathrm{Hr} \cdot \mathrm{Ft}^{2}$ in the plane of the collector. Data recorded shall be the average for at least a 20 minute period at quasi-steady state conditions.

1. Insolation rate.

2. Ambient temperature.

3. Wind Velocity and direction.

4. Absorber surface temperature at either 4 or 5 locations.

6.1 .2 Procedure

1. Mount test speclmen as described above.

2. Connect instrumentation.

3. Record data as described above.

$6.1 .3 \quad$ Results

The results for the stagnation test of the Solargenics collector are shown in Table II.: 
6.0 TECT REQU! FEMENTS AND PROCEDURES (Continued)

6.2 Collector Time Constant Test

Tested By: B. Henderson

Started: 7/15/78

Completed: $7 / 15 / 78$

6.2.1 Requirements

The collector time constant shall be determined by abruptly reduring the solar flux to zero. This will be done with the inlet temperature adjusted to within $\pm 2^{\circ} \mathrm{F}$ of ambient while the liquid is flowing at 1.5 GPM. This is the manufacturer's recommended flowrate. The differential temperature across the collector shall be monitored to determine the time required to reach the condition of:

$$
\frac{\Delta T(t)}{\Delta T_{i}}=.368
$$

where $\Delta T(t)$ is the differential temperature at time $t$ after the solar flux is reduced to zero and $\Delta T_{i}$ is the differential temperature prior to the shading of the solar collector: The liquid to be used as the collector heat transfer medium shall be as specified by the manufacturer.: If this liquid is not specified, use water as the fluid.

The following data will be recorded for the test:

(I) Solar flux.

(2) Ambient temperature.

(3) Inlet liquid temperature.

(4) Collector differential temperature.

(5) Liquid flow rate.

(6) specificd heat transfer medium.

\section{2 .2 Procedure}

1. Adjust the liquid flow rate to 1.57 GPM.*

2. Adjust the inlet temperature to ambient $\pm 2^{\circ} \mathrm{F}$.

3. Assure that the solar flux level is at least 250 $\mathrm{BTU} / \mathrm{Ft}^{2} \cdot \mathrm{Hr}$ and is not fluctuating.

4. Record data for five minutes at above stabilized conditions.

* The manufacturer's recommended flowrate. 
6.0 TEST REQUIREMENTS AND PROCEDURES (Continued)

6.2 Collector Time Constant Test (Continued)

6.2.2 Procedure (Continued)

5. Reduce the solar flux to zero by abruptly shading the collector from the sun. Mark on strip chart the moment when the collector is shaded.

6. Monitor and record the differential temperature across the collector until the ratio of $\mathrm{T}_{e}-\mathrm{T}_{i}$ is less than 0.30 .

$\mathrm{T}_{\mathrm{e}, \mathrm{ini}} \mathrm{T}_{\mathbf{i}}$

\subsubsection{Test Results}

The differential temperature across the collector was recorded on a strip chart. The chart speed on the recorder was adjusted such that the time-scale was approximately 10 inches in length. The inlet and outlet fluid temperatures, flowrates, and solar insolation rates were recorded at one-minute intervals through the test. Results of the test are shown in Figure 3. The standard ASHRAE formula of

$$
\frac{T_{e, t}-T_{i}}{T_{e, i n i}-T_{i}}=.368
$$

yields a time constant of five minutes and forty-two seconds. Data analysis methods are presented in section 7.2 . 
6.3 Collector Thermal Efficiency Test

Tested by: $\dot{B}$. Henderson

Started: $7 / 18 / 78$

Completed: $7 / 24 / 78$

6.3.1 Performance Criteria Requirements

The collector to be tested shall be pre-conditioned prior to initiation of the test. Pre-conditioning shall consist of stagnation heat in a non-operational. mode for three cumulative days in which the incident solar radiation measured in the plane of the collector shall be a mean of $1500 \mathrm{BTU} / \mathrm{Ft}^{2} / \mathrm{day}$ (406 Langleys). The colleotor shall be mounted in a location such that there will be no significant energy reflected or reradiated onto the collector from surrounding buildings or any other surfaces in the vicinity of the test stand for the duration of the test. In addition, the test stand shall be located so that no shadow will be cast onto the collector by any obstruction at any time during the test period. The test shall be conducted at times having weather conditions such that the integrated average insolation measured in the plane of the collector used for the computation of instantaneous efficiency values shall not be less than $200 \mathrm{BTU} / \mathrm{Ft}^{2} \cdot \mathrm{Hr}$. The air velocity across the collector surface shall be measured and recorded as part of the test data.

Thermal performance evaluation data shall be obtained at in let temperatures of $0,25,50$, and $100^{\circ} \mathrm{F}$ above the ambient temperature at the liquid flow rate of 1.5 GPM.

At least four "data points" shall be taken for each value of inlet temperature at the specified flowrate. The efficiency curve shall be established by "data points" that represent efficiency values determined by integrating the data over a time period equal to the time constant or 5 minutes, whichever is larger. The integrated value of incident solar enexgy will be divided into the integrated value of energy obtained from the collector to obtain the instantaneous efficiency.

The following data shall be recörded during the test at each operational condition.

1. Ambient temperature.

2. Collector inlet liquid temperature.

3. Collector outlet liquid temperature. 
6.3.1 Performance Criteria Requirements (Continued)

4. Collector differential temperature.

5. Differential pressure across collector.

6. Liquid flow rate.

7. Insolation rate.

8. Wind direction and speed.

\subsubsection{Test Procedure}

1. Mount the test specimen and its associated equipment on Test Bed \#2. The tilt angle shall be adjusted such that the solar incident angle is 0 degrees in the north-south plane at solar noon.

2. Assure that the data acquisition system is operational.

3. Establish the proper flowrate and inlet temperature for each test designation 1 through 4 specified below.

$\begin{array}{ccc}\text { Test No. } & \begin{array}{l}\text { Inlet Liquid Temperature } \\ \text { Differential above Exist- } \\ \text { ing Ambient Temp. OF }\end{array} & \begin{array}{l}\text { Liquid } \\ \text { Flowrate }\end{array} \\ & 0 & \frac{\text { GPM }}{1} \\ 2 & 25 & 1.5 \\ 3 & 50 & 1.5 \\ 4 & 100 & 1.5\end{array}$

4. Continuously adjust the inlet temperature and flow rate to maintain the desired "data point" characteristics. Monitor the test parameters by using the teletype at the test site.

5. Inform the data control group that the testing has been terminated. Label and save the printout from teletype as a record. 
The results of the thermal efficiency tests are presented in Figure 4. Table III contains the supporting data obtained during the tests. Data analysis methods are presented in section 7.1 . 
6.4 Incident Angle Modifier Test

Tested by: B. Henderson

Started: $7 / 20 / 78$

Completed: $7 / 25 / 78$

6.4.1 Reguirements

The collector incident angle modifier shall be determined by tilting the collector such that the east-west radiation incidence angles shall be $30^{\circ}, 40^{\circ}$ and $60^{\circ}$ with respect to $0^{\circ}$ at solar noon. The liquid flow rate shall be 1.5 GPM with the inlet temperature controlled to within $\pm 2^{\circ} \mathrm{F}$ of ambient. Since these tests are being performed at outdoor conditions, the inlet liquid temperature should be maintained as close as practical to ambient. The tests shall be conducted with a continuous direct solar flux rate greater than 240 $\mathrm{BTU} / \mathrm{Hr} \cdot \mathrm{Ft}^{2}$, when the wind speed is less than approximately $2 \mathrm{mph}$. The following data shall be recorded during the test.

(1) Collector tilt angles.

(2) Ambient air temperature.

(3) Collector inlet liquid temperature.

(4) Collector outlet liquid temperature.

(5) Collector differential temperature.

(6) Collector differential pressure.

(7) Incident solar flux level.

(8) Liquid flow rate through the collector.

\subsubsection{Procedure}

1. Set up collector at required tilt angle.

2. Establish required flowrate.

3. Establish required inlet temperature.

4. Assure adequate solar flux level.

5. Record data for five minutes at above stabilized conditions.

6. Repeat above steps as necessary to obtain required data for each tilt angle. 
6.4 Incident Angle Modifier Test (Continued)

6.4.3 Results

The results of the incident angle modifier test are shown in Figure 5. Table IV contains the supporting data obtained during the test. 
6.0 TEST REQUIREMENTS AND PROCEDURES (Continued)

$6.5 \quad$ Collector Load Test

Tested BY: : B. Henderson

Started: $6 / 27 / 78$

Completed: $6 / 27 / 78$

6.5.1 Reguirements

One solar collector shall be subjected to load testing. The specified load requirements are listed in Table $\mathrm{V}$. The collector shall be mounted as indicated in Figure 2 and shall be oriented such that the glazing is horizontal. Uniform loads shall be applied by means of a transparent flexible diaphragm which can be covered with a uniform layer of transparent liquid of varying depths to obtain the desired load variations. If either breakage or leakage to the collector occurs before all six test steps have been conducted, the load testing shall be discontinued. If it is determined that the failure is the result of a collector which is not representative of the vendor's normal product, the collector shall be replaced and the load test started over. If it is determined that the ultimate load capability of the collector has been reached, the load testing shall be terminated.

\section{$6.5 .2 \quad$ Procedure}

1. Mount the collector in the horizontal plane:

2. Place the load frame with liner over the collector.

3. Fill the load frame liner with water to a level corresponding to the step 1 load indicated in paragraph 5.5 .3 and let stand for five minutes.

4. Drain and remove the load frame.

5. Flush the collector exposed surface with water and inspect for leaks.

6. If the collector leaked or was damaged due to the load, record and indicate what the load level is.

7. If the rollector does not leak and is not damaged, record the load level and repeat steps 3 - 5 for the next load level.

\subsubsection{Results}

The results of the load test are shown in Table $V$. 
The analysis of data contained in this report is in. accordance with the National Bureau of Standards recommended approach. This approach is outlined below.

The efficjency of a collector is stated as:

$$
n=\frac{q_{u} / A}{I}=\frac{\dot{m} C_{t f}\left(t_{f, e}-t_{f, i}\right)}{I}
$$

where:

$$
\begin{aligned}
& \begin{aligned}
& q_{u}= \text { rate of useful energy extracted frum the } \\
& \text { Solar collector (B'Tu/Hr) }
\end{aligned} \\
& \text { A }=\text { Gross colilector area }\left(\mathrm{Ft}^{2}\right) \\
& I=\text {. Total solar energy incident upon the plane of } \\
& \text { the solar collector per unit time per unit } \\
& \text { area }\left(\mathrm{BTU} / \mathrm{Hr} \cdot \mathrm{Ft} \mathrm{C}^{2}\right) \\
& \dot{m} \text {. Mass flow rate of the transfer liquid through } \\
& \text { the colfector per unit area of the collector } \\
& \left(\mathrm{Lbm} / \mathrm{Ft}^{2} \cdot \mathrm{Hr}\right) \\
& C_{t f}=\text { specific heat of the transfer liquid (BTU/Lb. }{ }^{\circ} F \text { ) } \\
& \begin{aligned}
t_{f, e}= & \begin{array}{l}
\text { Temperature of the transfer liquid leaving the } \\
\text { collector }\left({ }^{\circ} \mathrm{F}\right)
\end{array}
\end{aligned} \\
& \begin{aligned}
t_{f, i}= & \text { Temperature of the transfer liquid entering the } \\
& \text { collector }\left({ }^{\circ} \mathrm{F}\right)
\end{aligned}
\end{aligned}
$$

Rewriting Equation (1) in terms of the total collector area yield:

$$
n=\frac{(\dot{i} A) c_{t f}\left(t_{f, e}-t_{f, i}\right)}{(I A)}=\frac{\dot{M} c_{t f}\left(t_{f, e}-t_{f, i}\right)}{P_{i}}
$$

Notice that:

$\mathrm{P}_{i}=I A=$ Total Power Incident on the collector. $\dot{m} A=\dot{M}=$ Total Mass Flow Rate through the collector. Therefore $\dot{M} c_{t f}\left(t_{f, e}-t_{f, i}\right)=$ Total Power collected by the collector. 
7.1 Thermal Performance Test (Continued)

Substitution in Equation (2) results, in:

$$
n=\frac{\text { Pabs }}{\text { Pinc }}
$$

where:

$$
\begin{aligned}
& \text { Pabs }=\text { Total collected power } \\
& \text { Pinc }=\text { Total incident power }
\end{aligned}
$$

This value of efficiency is expressed as a percentage by multiplying by 100. This expression for percent efficiency is:

$$
\text { Collector Efficiency }=\frac{\text { Pabs }}{\text { Pinc }} \times 100
$$

or from Equation (2), collector efficiency is defined by the equation:

$$
\text { \& Eff. }=\frac{\dot{M} c_{t f}\left(t_{f, e}-t_{f, i}\right)}{\text { Pinc }} \times 100
$$

Each term in Equation (5) was measured and recorded independently during the test. The calculated values of efficiency were determined at sixty-second intervals. The mean value of efficiency was determined over a fiveminute period during which the test conditions remained in a quasi-steady state. Each five-minute period constitutes one "data point". as is graphically depicted on a plot of percent efficiency versus

$$
\left(t_{i}-t_{a} / I\right)
$$

where:

$$
\begin{aligned}
& t_{\mathbf{i}}=\text { Liquid inlet temperature }\left({ }^{\circ} \mathrm{F}\right) \\
& \mathrm{t}_{\mathbf{a}}=\text { Ambient temperature }\left({ }^{\circ} \mathrm{F}\right) \\
& \mathrm{I}=\text { Incident flux per unit area }\left(\mathrm{BTU} / \mathrm{Hr} \cdot \mathrm{Ft}^{2}\right)
\end{aligned}
$$

The abscissa term $\left(\left(t_{i}-t_{a}\right) / I\right)$ was used to normalize the effect of operating at different values of $I, t_{i}$ and $t_{a}$. The results are found in Figure 4 . The results of second order polynomial analyses are also shown in Figure 4. The second order polynomial to best describe the test results is:

$$
\text { Efficiency }=a_{0}+a_{1} \tau+a_{2} \tau^{2}
$$


7.0

ANALYSIS (Continued)

7.1

Thermal Performance Test (Continued)

where

$$
\tau=\left(t_{i}-t_{a}\right) / I
$$

and the coefficients are determined to be:

$\begin{array}{cr}\text { Flow Rate (GPM) } & \frac{1.5}{a_{0}} \\ a_{1} & 0.589 \\ a_{2} & -0.604 \\ & -0.688\end{array}$


7.2 Time Constant Test

Two methods are proposed by ASHRAE 93-77 for conducting a time constant test; however, due to facility limitations, the first method was used. This method consisted of shading the collector and maintaining a constant flow rate and inlet temperature while obtaining data.

According to the definition of time constant given in 9377 , it is the time required for the ratio of the differential temperature at time $\tau$ to the initial differential temperature to reach .368 , when solar insolation is reduced to zero. It can be expressed as:

$$
\frac{T_{f, e, \tau}-T_{f, i}}{T_{f, e, i n i}-T_{f, i}}=.368
$$

If the inlet liquid temperature cannot be controlled to equal the ambient air temperature, then the following equation must be used

$$
\frac{F_{R} U_{L}\left(T_{f, i}-T_{a}\right)+\frac{\dot{m} C p}{\overline{A g}}\left(T_{f, e, \tau}-T_{f, i}\right)}{F_{R} U_{L}\left(T_{f, i}-T_{a}\right)+\frac{\dot{m} C p}{\overline{A g}}\left(T_{f, e, i n i}-T_{f, i}\right)}=.368
$$

where:

$$
\begin{aligned}
& \mathrm{T}_{\mathrm{f}, \mathrm{e}, \tau} \boldsymbol{\text { Exit }} \text { liquid temperature at time } \tau \\
& \mathbf{T}_{f, i} \quad \text { Inlet liquid temperature } \\
& \text { Tf,e,ini Initial exit liquid temperature } \\
& \dot{m} \quad \text { Liquid mass flow rate, Lb/Hr } \\
& \mathrm{C}_{\mathrm{p}} \quad \text { Specific heat of liquid, } \mathrm{BTU} / \mathrm{Lb} \cdot \mathrm{e}_{\mathrm{F}} \\
& \text { Ag Gross collector area, } \mathrm{ft}^{2} \\
& F_{R} U_{L} \quad \text { Negative of the slope determined from }
\end{aligned}
$$

The inlet temperature was maintained within $\pm 2^{\circ} \mathrm{F}$ of the ambient, hence equation (1) was used for evaluation. From Figure 3 the time constant was determined to be 5 minutes and 42 seconds. 
7.0 ANALYSIS (Continued)

7.3 Incident Angle Modifier Test

Two methods are proposed by ASHRAE 93-77 for incident angle modifier tests. Method 1 (tilting the collector) was used for the solargenics collector. Incident radiation angles of $0^{\circ}, 30^{\circ}, 40^{\circ}$ and $60^{\circ}$ with respect to the normal of the collector surface were used.

According to 93-77, the incident angle modifier is defined as

$$
K_{c i \tau}=\frac{\pi}{F_{R}(\tau \alpha) n}
$$

where $\eta=$ efficiency at tilted angle.

$$
\begin{aligned}
F_{R}(\alpha \tau) n= & \text { Intercept of efficiency curve } \\
& \text { at normal incident angle }=0.589
\end{aligned}
$$

For cquation (1) to be applicable, the inlet temperature must be controlled to within $\pm 2{ }^{\circ} \mathrm{F}$ of the ambient air temperature. In cases where the iniet temperature cannot be controlled to within $\pm 2^{\circ} \mathrm{F}$, the following equation must be used to evaluate the incident angle modifier.

where

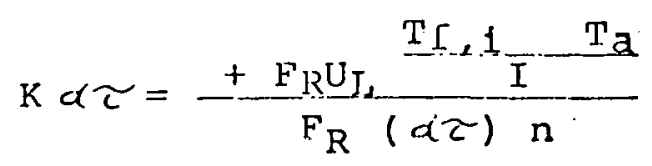

$\mathrm{F}_{\mathrm{R}} \mathrm{U}_{\mathrm{L}}$ is the negative of the slope determined.

from the thermal efficiency curve, $=0.82$

Table IV shows that the in let temperatures were all within $\pm 2^{\circ} \mathrm{F}$ of ambient air temperature. Hence, equation (1) was used for evaluation.

The results of this compulation are shown on Table IV and plotted agalinst incident angle in Figure 5. 
TABLE I

DESIGNATION OF INSTRUMENTATION FOR SOLAR COLLECTOR TESTS

Meas. Sensor Instrument

No. Location

Tiol Collector Absorber Plate 1

TlO2 Collector Absorber

Plate 2

Tl03 Collector Absorber Plate 3

T104 Coilector Absorber Elate 4

T107 Coliector Abscrber Flate 5

Tl05 Collector Fluid Inlet

Tl06 Coliector Fluid Outlet

Tl09 Ambient Air

F001 Fluid Flow Rate/ Pressure Transducer

I001 Solar Flux

T008 Nozzle Temperature

PDI00 Across Collector

TDI00 Across Collector

\section{Output Range}

$20 \mathrm{MV}$

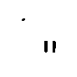

\section{"}

"1

"

11

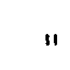

$"$

$0-5 V D C$

$0-20 \mathrm{MV}$

$0-20 \mathrm{MV}$

$0-20 \mathrm{MV}$
Meas.

Range

$-50-400^{\circ} \mathrm{F}$

"I

11

"

$60-250^{\circ} \mathrm{F}$

$60-250^{\circ} \mathrm{F}$

$40-100^{\circ} \mathrm{F}$

$35-130$ ACFM

$0-7.43 \mathrm{BTU} /$

$\mathrm{Hr} \cdot \mathrm{Ft}^{2}$

$60-250^{\circ} \mathrm{F}$

$0-10$ PSID

$0-140^{\circ} \mathrm{F}$
Serial No.

Model No.

Mfg.* . RTS $-4175-100$

II.

"I

11

35

RTS-4135-100

85

RTS $-4135-100$

100

RTS-4135-100

71712-1

52D0010AM6

$24134=3 \quad P S P$

50

RTS $-4135-100$

Statham Differential Pressure Transducer 12261

* Instailed by Collector Manufacturer. 


$\begin{array}{lr}\begin{array}{l}\text { Ambient Air } \\ \text { Temp., }{ }^{\circ} \mathrm{F}\end{array} & 89.0 \\ \text { Solar Flux } \\ \text { BTU/Hr.Ft } \\ \text { Wind } & 288.9 \\ \text { Sensor Location } 1 & \text { Calm } \\ \text { Temp., }{ }^{\circ} \mathrm{F} & 341.5 \\ \text { Sensor Location 2 } & \\ \text { Temp., }{ }^{\circ} \mathrm{F} & \\ \text { Sensor Location } 3 & 327.1 \\ \text { Temp., }{ }^{\circ} \mathrm{F} & \\ \text { Sensor Location } 4 & 335.5 \\ \text { Temp., }{ }^{\circ} \mathrm{F} & \end{array}$

NOTE: Sensors installed by manufacturer. Sensors 2 and 4 partially shaded by collector glazing support crossbar.

Non-standard sensor locations - See Figure 2. 
TABLE III

THERMAL PERFORMANCE TEST DATA FOR THE SOLARGENICS COLLECTOR

Page 1 of 2

\begin{tabular}{|c|c|c|c|c|c|c|c|c|}
\hline $\begin{array}{l}\text { Date } \\
\text { Wind speed and Direction }\end{array}$ & $\begin{array}{r}7 / 18 \\
5 E\end{array}$ & $\begin{array}{l}7 / 18 \\
5 W\end{array}$ & $\int^{7 / 20}$ & $\frac{7 / 20}{5 W}$ & $\begin{array}{r}7 / 24 \\
7 w\end{array}$ & $\begin{array}{r}7 / 24 \\
5 W\end{array}$ & $\begin{array}{r}7 / 24 \\
7 \mathrm{E}\end{array}$ & $7 / 24$ \\
\hline $\begin{array}{l}\text { Ambient Air Tempera- } \\
\text { ture }\left(T_{\mathbf{a}}\right),{ }^{\circ} \mathrm{F}\end{array}$ & 89.5 & 90.0 & 92.0 & 92.5 & 92.0 & 91.9 & 91.3 & 91.6 \\
\hline $\begin{array}{l}\text { Fluid Inlet Tempera- } \\
\text { ture }\left(T_{i}\right),{ }^{\circ} \mathrm{F} .\end{array}$ & 91.8 & 92.0 & 91.7 & 91.9 & 115.1 & 115.2 & 115.4 & 115.5 \\
\hline $\begin{array}{l}\text { Fluid Outlet Temp- } \\
\text { erature }\left(\mathrm{T}_{e}\right),{ }^{\circ} \mathrm{F}\end{array}$ & 106.2 & 106.2 & 105.4 & 105.9 & 129.7 & 129.6 & 129.9 & 129.6 \\
\hline $\begin{array}{l}\text { Differential Fluid } \\
\text { Temperature }(\Delta \mathrm{T}),{ }^{\circ} \mathrm{F}\end{array}$ & 14.4 & 14.2 & 13.7 & 14.0 & 14.6 & 14.4 & 14.5 & 14.1 \\
\hline $\begin{array}{l}\text { To=al Solar Flux } \\
\text { (I), BTU/Hr. Ft }{ }^{2}\end{array}$ & 303.6 & 310.3 & 282.6 & $28: 3.0$ & 320.6 & 314.9 & 316.4 & 314.1 \\
\hline Flow Rate, GPM & 1.58 & 1.58 & 1.54 & 1.54 & 1.54 & 1.54 & 1.55 & 1.55 \\
\hline$\left(T_{i}-T_{a}\right) / I$ & .01 & .01 & .00 & .00 & .07 & .07 & .08 & .08 \\
\hline $\begin{array}{l}\text { Efficiency } \\
(\varkappa), z\end{array}$ & 58.7 & 56.6 & 58.4 & 59.6 & 54.6 & 54.8 & 55.2 & 54.1 \\
\hline Specific Gravity & 0.996 & 0.996 & 0.996 & 0.996 & 0.989 & 0.989 & 0.989 & 0.989 \\
\hline
\end{tabular}
$n=\frac{\text { GPM } \times 8.33 \times 60 \times S G \times \Delta T}{A}$
Area $=63.54 \mathrm{Ft}^{2}$
Fluid $\mathrm{H}_{2} \mathrm{O}$ 
TABLE III (Continued)

Page 2 of 2

\begin{tabular}{|c|c|c|c|c|c|c|c|c|}
\hline $\begin{array}{l}\text { Date } \\
\text { Wind Speed and Direction }\end{array}$ & $7 / 24$ & $\begin{array}{r}7 / 24 \\
8 W\end{array}$ & $7 / 24$ & $\begin{array}{l}7 / 24 \\
8 W\end{array}$ & $\begin{array}{cc}7 / 18 & \\
& 5 \mathrm{E}\end{array}$ & $7 / 18$ & $7 / 18$ & ${ }^{7 / 18} 10 \mathrm{~W}$ \\
\hline $\begin{array}{l}\text { Ambient } \Lambda \text { ir Tempera- } \\
\text { ture }\left(T_{a}\right),{ }^{\circ} \mathrm{F}\end{array}$ & 93.5 & 93.0 & 92.5 & 92.3 & .93 .9 & 93.9 & .94 .5 & 95.2 \\
\hline $\begin{array}{l}\text { Fluid Inlet Tempera- } \\
\text { ture }\left(T_{i}\right),{ }^{\circ} \mathrm{F} .\end{array}$ & 145.4 & 145.4 & 145.3 & 145.1 & 187.8 & 189.4 & 189.9 & 189.9 \\
\hline $\begin{array}{l}\text { Fluid outlet Temp- } \\
\left.\text { erature (' } \mathrm{l}_{\mathrm{e}}\right),{ }^{\circ} \mathrm{F}\end{array}$ & 158.3 & 158.2 & 158.6 & 158.4 & 195.4 & 197.5 & 199.4 & 199.4 \\
\hline $\begin{array}{l}\text { Differential Fluid } \\
\left.\text { Temperature }(\Delta)^{\prime}\right),{ }^{\circ} F\end{array}$ & 12.9 & 12.8 & 13.3 & 13.3 & 7.6 & B. 1 & 9.5 & 9.5 \\
\hline $\begin{array}{l}\text { Total Solar Elux } \\
(I), \text { BTU/:Ir } \cdot \text { Ft }^{2}\end{array}$ & 322.4 & 324.6 & 323.4 & 331.4 & 300.4 & 302.4 & 315.8 & 308.0 \\
\hline Flow Rate, GPM & 11.51 & 1.51 & 1.51 & 1.51 & 1.57 & 1.57 & 1.57 & 1.57 \\
\hline $\begin{array}{l}\left(T_{i}-T_{a}\right) / I \\
{ }^{F} \cdot H r \cdot F t^{2} / B T U\end{array}$ & .16 & .16 & .16 & .16 & .31 & .32 & .30 & .31 \\
\hline $\begin{array}{l}\text { Efficiency } \\
(\eta),\end{array}$ & 46.8 & 46.1 & 48.0 & 46.9 & 30.2 & 31.9 & 35.9 & 36.8 \\
\hline Specific Gravity & .984 & .984 & .9 .34 & $.9 \& 4$ & .966 & .966 & .966 & .966 \\
\hline
\end{tabular}


TABLE IV

INCIDENT ANGLE MODIFIER TEST DATA FOR THE SOLARGENICS COLLECTOR

\begin{tabular}{|c|c|c|c|c|}
\hline Angle & $0^{\circ}$ & $30^{\circ}$ & $40^{\circ}$ & $60^{\circ}$ \\
\hline $\begin{array}{l}\text { Ambient Air Tempera- } \\
\text { ture }\left(T_{a}\right),{ }^{\circ}\end{array}$ & 92.0 & 89.5 & 87.8 & 88.5 \\
\hline $\begin{array}{l}\text { Fluid Inlet Tempera- } \\
\text { ture }\left(T_{i}\right),{ }^{\circ} \mathrm{F} \text {. }\end{array}$ & 91.7 & 91.5 & 90.3 & 86.5 \\
\hline $\begin{array}{l}\text { Fluid outlet Temp- } \\
\text { erature }\left(T_{e}\right),{ }^{\circ} \mathrm{F}\end{array}$ & 105.4 & 106.1 & 103.5 & 93.7 \\
\hline $\begin{array}{l}\text { Differential Fllid } \\
\text { Temperature }(\Delta T),{ }^{\circ} \mathrm{F}\end{array}$ & 13.7 & 14.6 & 13.2 & 7.2 \\
\hline $\begin{array}{l}\text { Total Solar Flux } \\
\text { (I), BTU/Hr } \cdot \mathrm{Ft}^{2}\end{array}$ & 282.6 & 289.3 & 265.0 & 190.4 \\
\hline Flow Rate, GPM & 1.54 & 1.50 & 1.50 & 1.56 \\
\hline $\begin{array}{l}\left(T_{i}-T_{a}\right) / I \\
\cdot F \cdot H r \cdot F t^{2} / B T U\end{array}$ & 0 & 0 & 0 & 0 \\
\hline $\begin{array}{l}\text { Efficiency } \\
(n), 8\end{array}$ & 58.4 & 59.3 & 57.4 & 46.4 \\
\hline $\begin{array}{l}\text { Efficiency Ratig Based } \\
\text { g8 çurve F1t yaje of }\end{array}$ & 0.99 & 1.01 & 0.97 . & 0.79 \\
\hline
\end{tabular}


TABLE V

RESULTS OF LOAD TESTING

Service Load Steps

\begin{tabular}{|c|c|c|c|}
\hline Step No. & Load $\left(\mathrm{Lb} / \mathrm{Ft}^{2}\right)$ & Pass/Fail & Comments \\
\hline 1 & 10 & Pass & (See Note) \\
2 & 20 & Pass & \\
3 & 30 & Pass & \\
4 & 50 & Pass & \\
5 & 80 & Pass & \\
\hline 6 & 120 & Pass & \\
\hline
\end{tabular}

* NOTE: Due to the size of the collector, the load test was performed on only one glazing panel rather than the entire collector. 
O-Platinum kesistance The rimimeter (PRT)

D Therrocouple

O- Flow Heter

$\otimes-$ Solar Flux

$\Delta-$ Differentjal Pressurei

$\otimes-$ Differentiar Therinopile

T.T Wind Velofity

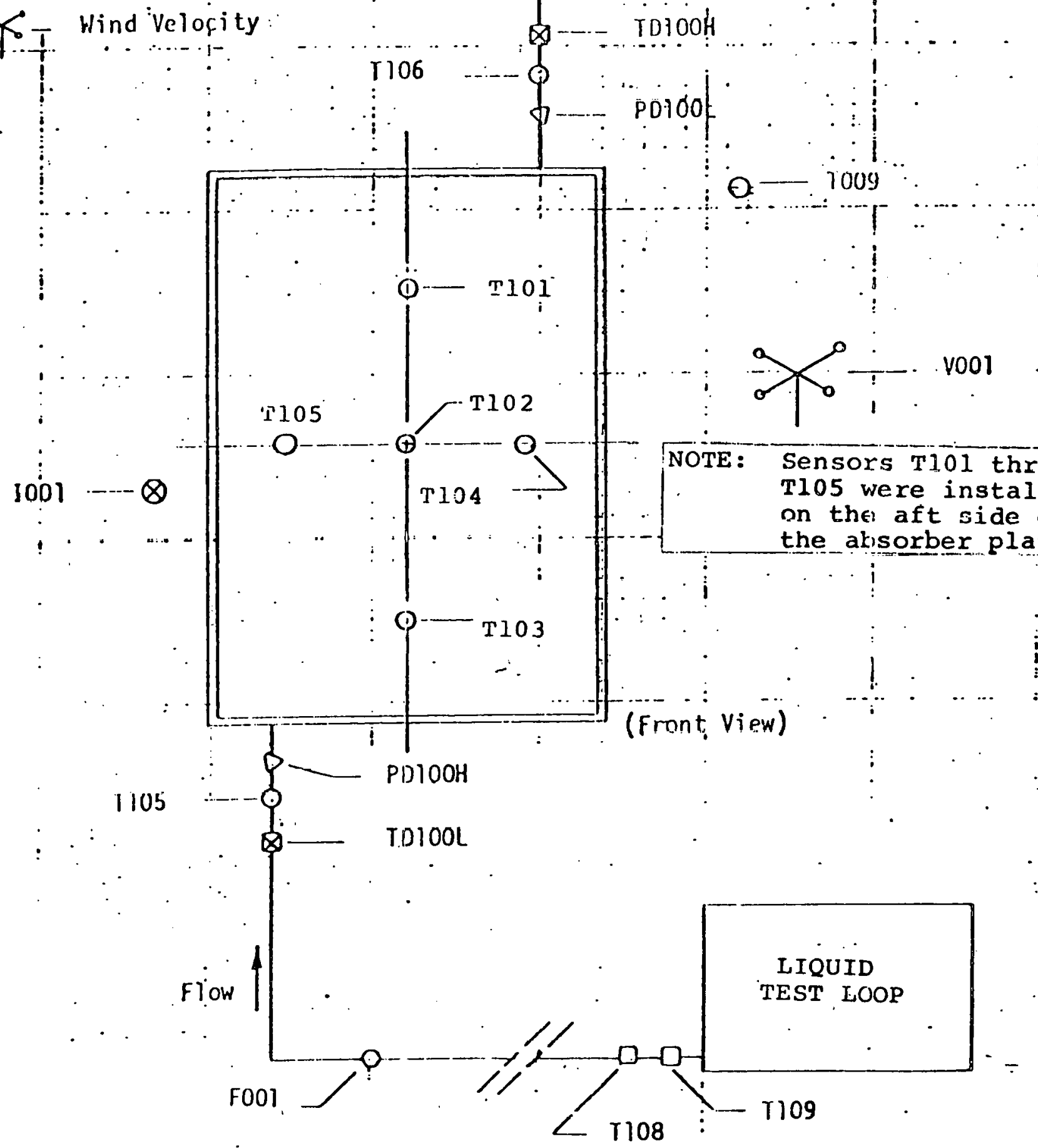

Figure 1. Instrumentation Lfgcations for Liquid Collector Test 


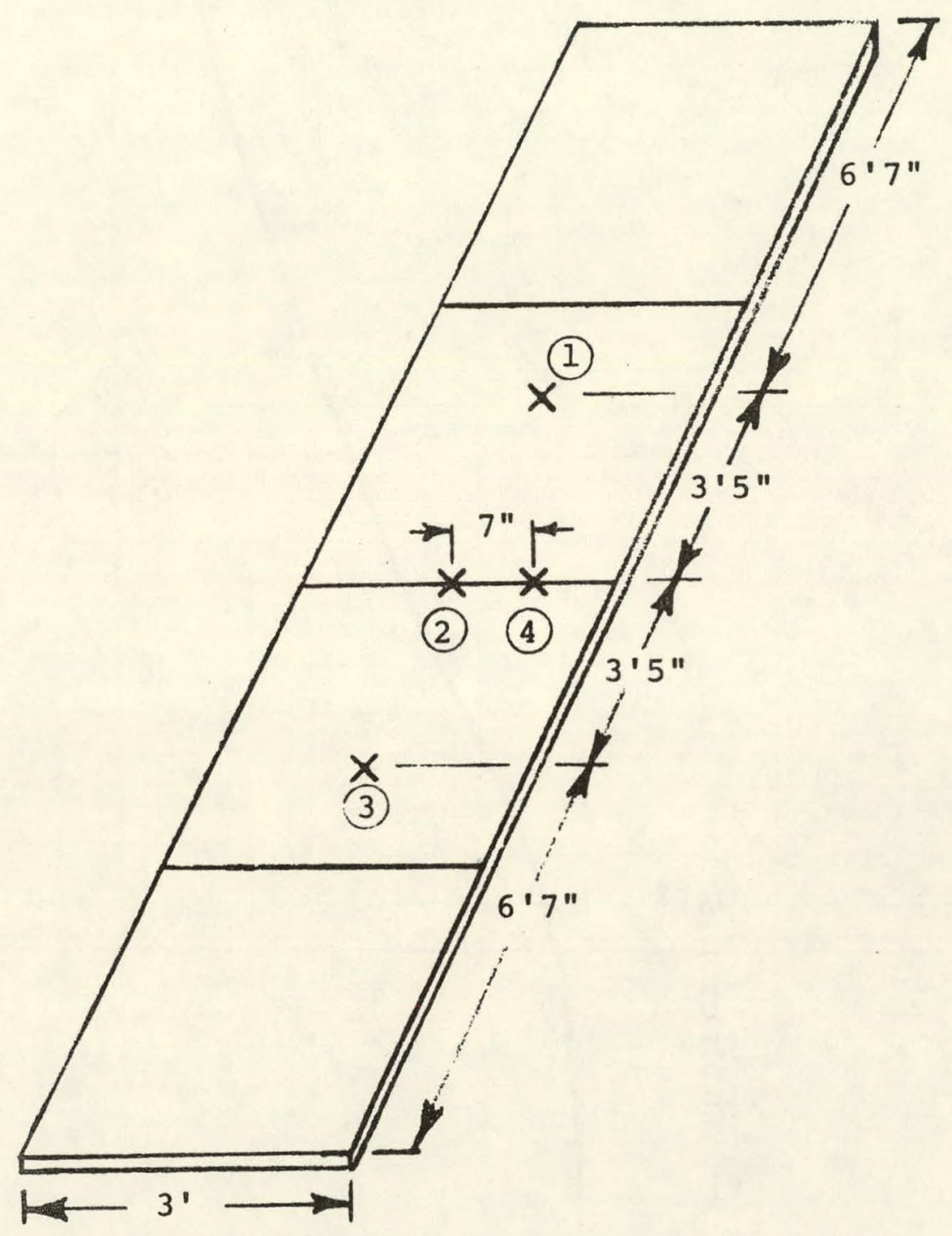

Note: Temperature sensors (1) through (4) were installed by the manufacturer. Sensors (2) and (4) are partially shaded by the collector glazing support cross bar. Non-standard sensor locations.

Figure 2. Schematic of the Solargenics Collector with Stagnation Temperature Sensor Locations 


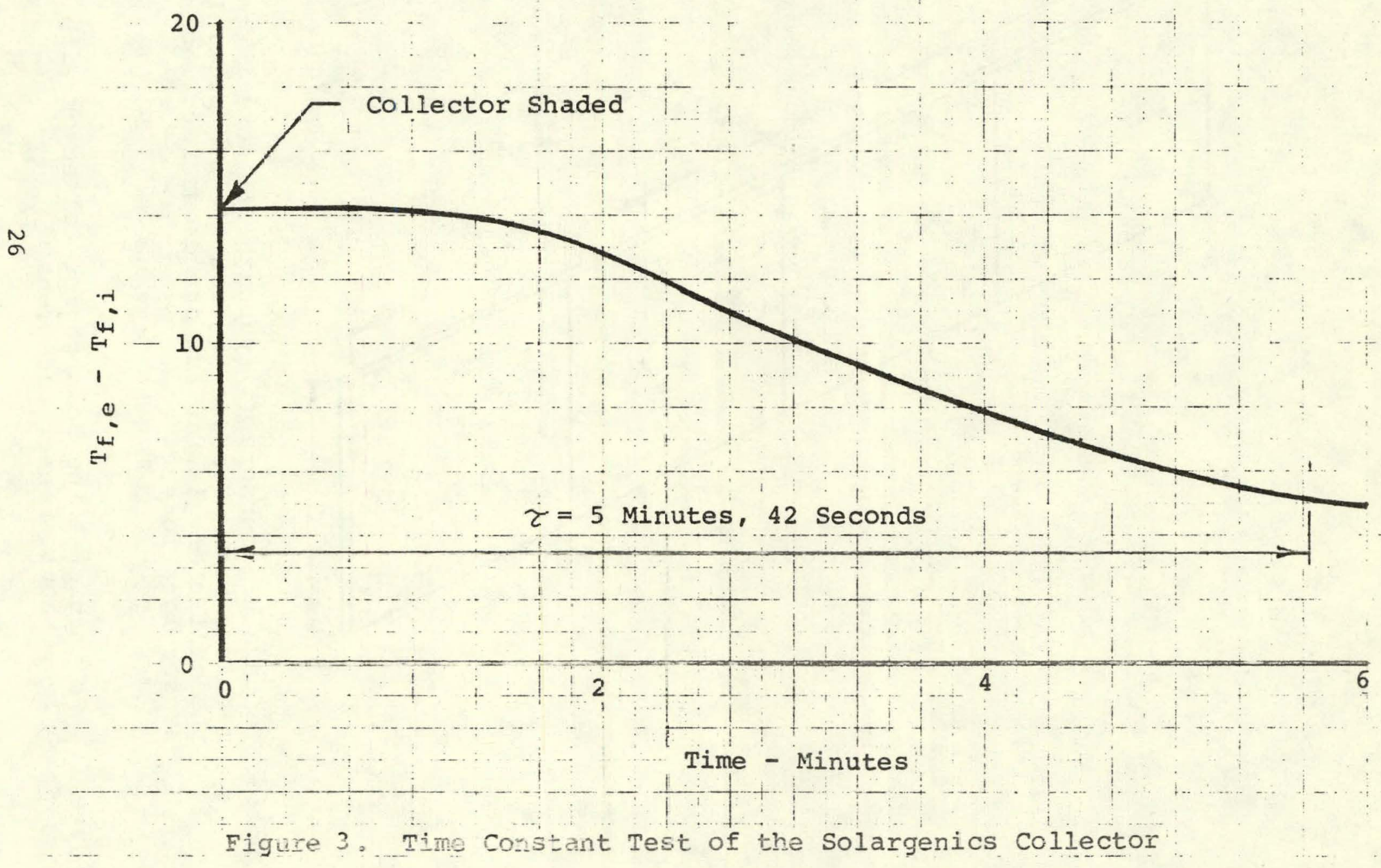




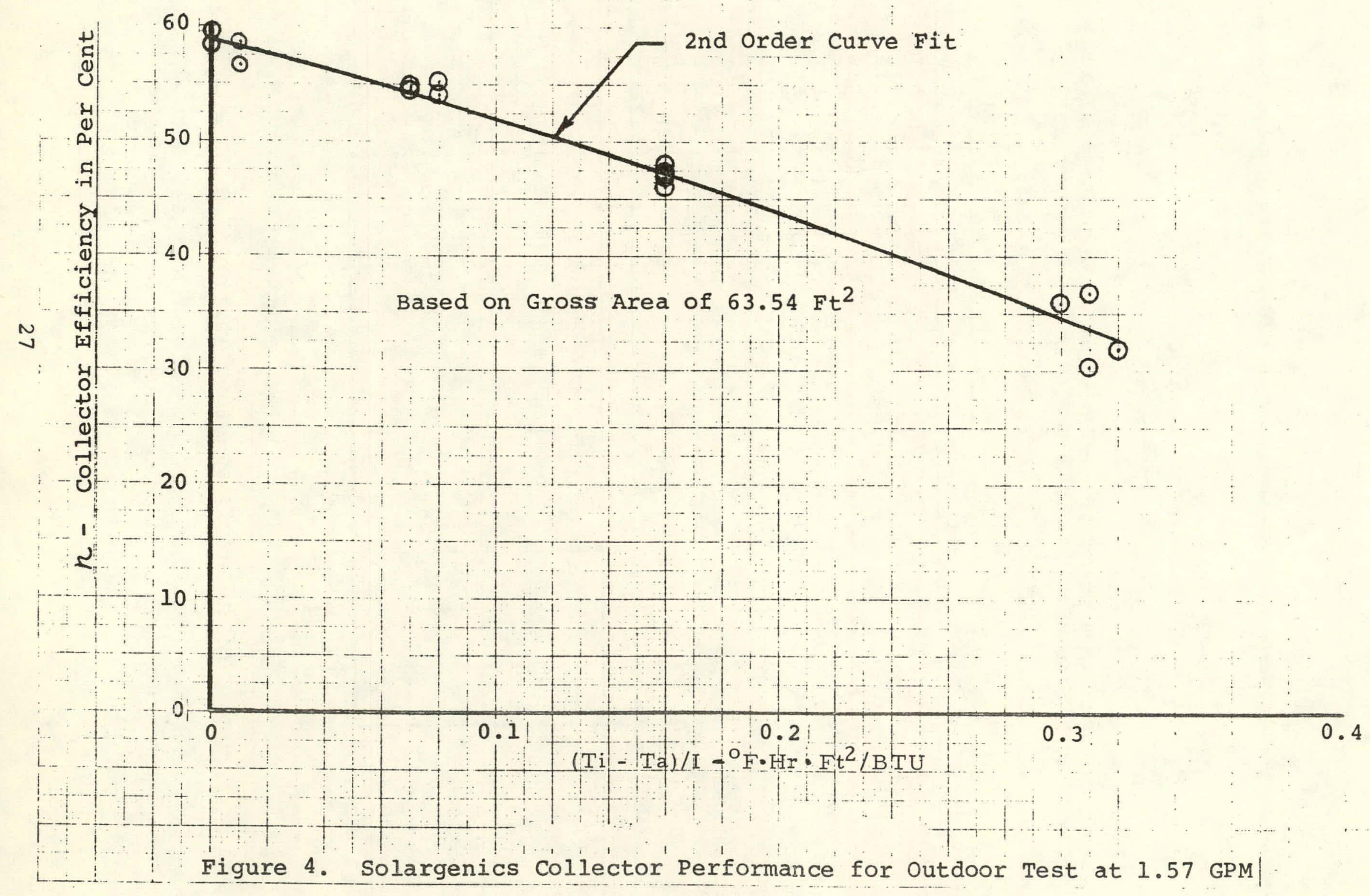




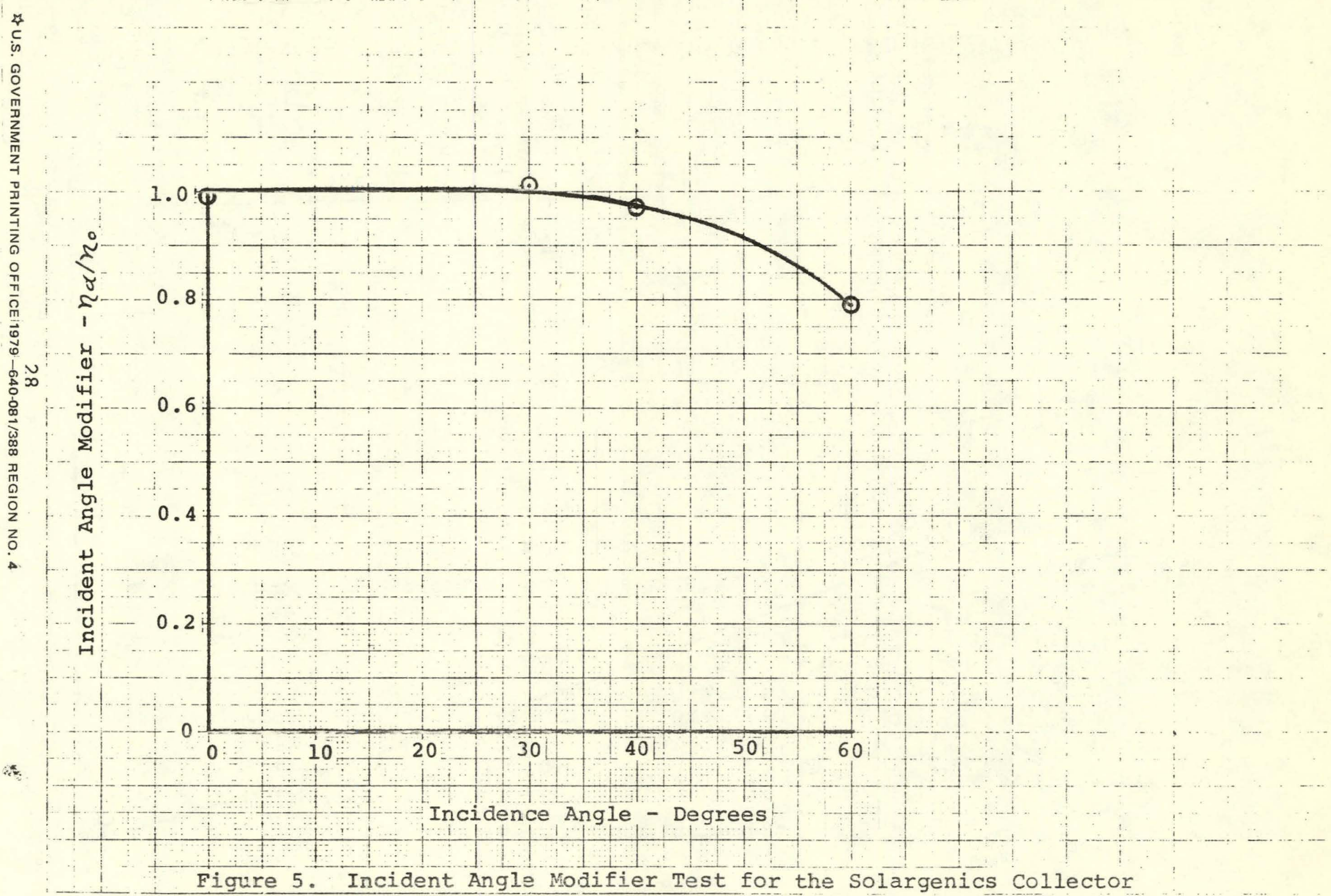

